Chapman University

Chapman University Digital Commons

Food Science Faculty Articles and Research

Science and Technology Faculty Articles and

Research

$10-12-2018$

\title{
Acidulant Effect on Greening, Reducing Capacity, and Tryptophan Fluorescence of Sunflower Butter Cookie Dough During Refrigerated Storage
}

Joele Tsopkeng Atonfack

Chapman University

Zeynep Akyol Ataman

Mt.San Jacinto College, zataman@chapman.edu

Lilian M. Were

Chapman University, were@chapman.edu

Follow this and additional works at: https://digitalcommons.chapman.edu/food_science_articles

Part of the Botany Commons, Food Processing Commons, Other Food Science Commons, and the Other Plant Sciences Commons

\section{Recommended Citation}

Atonfack JT, Ataman ZA, Were LM. Acidulant effect on greening, reducing capacity, and tryptophan fluorescence of sunflower butter cookie dough during refrigerated storage. J Sci Food Agric. 2018; 99(5): 2186-2193. https://doi.org/10.1002/jsfa.9412

This Article is brought to you for free and open access by the Science and Technology Faculty Articles and Research at Chapman University Digital Commons. It has been accepted for inclusion in Food Science Faculty Articles and Research by an authorized administrator of Chapman University Digital Commons. For more information, please contact laughtin@chapman.edu. 
Acidulant effect on greening, reducing capacity, and tryptophan fluorescence of sunflower butter cookie dough during refrigerated storage

Running title Acidulant effect on greening and oxidation in sunflower butter cookie dough

\section{Name(s) of Author(s)}

Joele Tsopkeng Atonfack ${ }^{\dagger}$, Zeynep Akyol Atamanł, Lilian M. Were ${ }^{\dagger}$

\section{Author Affiliation(s)}

${ }^{\dagger}$ Food Science Program, Keck Center for Science and Engineering, Chapman University, One

University Dr, Orange, CA 92688, USA

$\ddagger$ Mt. San Jacinto College, Department of Biology, 1499 N. State Street, San Jacinto, CA 92583, USA

\section{Contact information for Corresponding Author}

${ }^{\dagger}$ Lilian Were, Ph.D.

Phone: 714-744-7895

Fax: 714-289-2041

Email: were@chapman.edu

Keck Center for Science and Engineering

One University Drive, Orange, CA 92866

This article has been accepted for publication and undergone full peer review but has not been through the copyediting, typesetting, pagination and proofreading process which may lead to differences between this version and the Version of Record. Please cite this article as doi: $10.1002 /$ jsfa. 9412 


\begin{abstract}
BACKGROUND: Sunflower seed derived butter can be a source of protein and phenolic antioxidants in refrigerated dough. Chlorogenic quinone-amino acid induced greening can however occur at alkaline $\mathrm{pH}$, which could result in less bioavailable conjugated phenol-amino acids. Acidulants were tested as potential anti-greening ingredients in refrigerated chemically leavened cookie dough. Effect of refrigerated storage time, leavening agents and acidulants on tryptophan fluorescence $(» \mathrm{ex}=280 \mathrm{~nm}$, »em=300-500), color (hunter LAB), reducing capacity (DPPH and Folin-Ciocalteu reagent reducing capacity/FCRC), and hydroxycinnamic acids were measured.

RESULTS: The $\mathrm{pH}$ range of acidified doughs was 4.83-6.98 compared to 7.65-9.18 in nonacidified leavened doughs after 24 days. Greening was higher in baking soda dough control $\left(\mathrm{a}^{*=}=-0.54\right)$ than baking powder dough control $\left(\mathrm{a}^{*}=2.98\right)$ after 24 days, attributed to higher $\mathrm{pH}$ (9.18) of the former compared to $\mathrm{pH} 7.14$ in the later. Tryptophan fluorescence intensity in baking soda dough decreased in the order: control $>$ glucono-delta lactone H citric acid after 24 days. The DPPH and FCRC of acidified doughs were greater than corresponding control doughs. CONCLUSION: The use of acidulants would prevent greening in sunflower dough without lowering its phenolic concentration, making use of sunflower butter in refrigerated dough for baked goods feasible.
\end{abstract}

Keywords: acidulants; baking soda; greening; hydroxycinnamic acids; sunflower butter; tryptophan 


\section{INTRODUCTION}

Sunflower seed derived spreads and butter can be a source of protein and phenolic antioxidants in refrigerated dough. The protein content of sunflower butter $(18 \mathrm{~g} / 100 \mathrm{~g})$ is similar to the estimated $21.88 \mathrm{~g}$ protein $/ 100 \mathrm{~g}$ of peanut butter ${ }^{1}$. However, peanuts are a source of major allergens in the West, and the leading cause of food allergenic death by anaphylaxis ${ }^{2}$. Sunflower butter could thus be an alternative to peanut butter cookie dough for those with peanut sensitivities.

Sunflower seeds used to make butter contain $0.29 \mathrm{~g} / \mathrm{Kg}-0.42 \mathrm{~g} / \mathrm{Kg}$ and $0.004-0.009 \mathrm{~g} / \mathrm{Kg}$ phenolic compounds in dehulled kernels and shells respectively. Chlorogenic acid (CGA) and its isomers 3 - and 4 caffeoylquinic acids represent $61-93 \%$ of the total phenol content in sunflower kernels ${ }^{3}$. Interaction between phenolic compounds such as CGA and limiting amino acids such as lysine, methionine, and tryptophan at high $\mathrm{pH}$ can decrease free amino acid content and hence nutritional value of sunflower protein $^{4-6}$. Chlorogenic acid (CGA) is oxidized to highly reactive electron rich quinone dimers at alkaline $\mathrm{pH}$. These quinones bind to protein to form green pigments in the presence of oxygen ${ }^{7-9}$.

Acidulants were hypothesized to prevent greening in chemically leavened sunflower dough and increase free phenolic compounds. Baking acidulants like citric acid and glucono delta lactone (GDL) can react with leavening agents in aqueous solutions to improve dough leavening by $\mathrm{CO}_{2}$ production ${ }^{10}$. Non-green refrigerated sunflower dough could be a phenolic rich alternative to ready to bake peanut dough since peanuts contains $2.42 \mathrm{E}-03 \mathrm{~g} / \mathrm{Kg}$ chlorogenic 
acid, which is about 100 times lower than the chlorogenic acid $(0.24-0.28 \mathrm{~g} / \mathrm{Kg})$ content in sunflower kernel ${ }^{3,11}$.

Yabuta et al., ${ }^{9}$ showed that ascorbic acid reversed the green pigmentation in chlorogenic acid-protein solutions to yellow, making acidulants potentially suitable for preventing or lowering greening in sunflower cookie dough. Despite a desire for alternative non-allergenic proteins, few studies have been published on ready to bake sunflower butter cookie dough ${ }^{8}$. This study was designed to analyze the effect of glucono delta lactone and citric acid on (i) greening (ii) hydroxycinnamic acid content and (iii) associated antioxidant capacity and tryptophan of sunflower butter cookie dough during 24 days of refrigerated storage at $8^{\circ} \mathrm{C}$.

\section{EXPERIMENTAL}

\section{Experimental design and sunflower butter cookie dough preparation}

Two batches of sunflower cookie dough totaling $250 \mathrm{~g}$ for each treatment were prepared as described by Liang and $\mathrm{Were}^{8}$ with the following modifications: Leavening agents used were $1.5 \mathrm{~g}$ of baking soda (Trader Joe's, USA ) or baking powder (Clabber girl baking powder, IN, USA; UPC: 019900003332), xanthan gum (1.75g) added as recommended by Simsek ${ }^{12}$. The acidulants: citric acid $(0.522 \mathrm{~g})$ and GDL $(1.154 \mathrm{~g})$ were added to dough except in the controls. The amount of leavening acids added was a function of the neutralization value of each acidulant 10 .

Mass of acid $(\mathrm{g})=\frac{* \text { mass of leavening agent }(\mathrm{g})}{\text { Neutralization value }} * 100+0.3 \mathrm{~g} \quad$ Equation 1 
where leavening agent was either baking soda $\left(\mathrm{NaHCO}_{3}\right)$ or baking powder composed of $\mathrm{NaHCO}_{3}, \mathrm{SALP}$ and filler starch (universal product code: 041617007501). The neutralization value (amount of acid needed to neutralize bicarbonate) of citric acid and GDL was 159 and 52 respectively. Additional $0.3 \mathrm{~g}$ of each acid from preliminary physical observation of dough was added to each acidified dough treatment to compensate for the alkaline $\mathrm{pH}$ of maple syrup. Another control without leavening agents and acidulant was used to assess the effect of both leavening agents and acidulants on tryptophan fluorescence intensity.

\section{Color and pH changes of sunflower cookie dough}

Dough samples $(50 \mathrm{~g})$ were weighed into plastic cups and the surface color (hunter L*, $\left.a^{*}, b^{*}\right)$ was measured as outlined by Liang and Were ${ }^{8}$. To determine $\mathrm{pH}$, distilled and deionized water (DDW) was boiled to $100^{\circ} \mathrm{C}$ for $20 \mathrm{~min}$ and cooled to room temperature to eliminate carbon dioxide from water. Dough samples $(0.6 \mathrm{~g})$ were dissolved in $10.0 \mathrm{~mL}$ DDW and homogenized using a ProScientific, Multi-prep Homogenizer 01-01620 (USA) for $180 \mathrm{sec}$ at $11963^{*} \mathrm{~g}$. The homogenized samples were incubated for $120 \mathrm{mins}$ at room temperature, centrifuged at $4000 \mathrm{~g}$ for 20 mins (Fisher, AccuSpin IR centrifuge) before $\mathrm{pH}$ of each sample supernatant was measured using a LabQuest ${ }^{\circledR} 2 \mathrm{pH}$ meter (Vernier Software \& Technology).

\section{Phenolic compounds, Folin-Ciocalteu and DPPH reducing capacity of sunflower cookie dough}

Dough $(0.6 \mathrm{~g})$ in $10 \mathrm{ml}$ methanol (Sigma-Aldrich, USA) was homogenized with a ProScientific, multi-prep homogenizer. Mixtures were then incubated for $12 \mathrm{~h}$ at 8 åd 
centrifuged at 4000* $\mathrm{g}$ for $20 \mathrm{~min}$. The supernatant was used for hydroxycinnamic acid and reducing capacity measurements.

Hydroxycinnamic (HA) compounds of 1:7 dough: methanolic solutions were quantified by measuring absorbance at 320nm in quartz cuvettes using a USB-650 Red tide Spectrometer (Ocean optics, Winter Park, FL USA) against CGA concentrations of 0.086- 0.69mM.

The Folin-Ciocalteu reducing capacity of $1 \mathrm{ml}$ of $6 \%$ methanolic extract of cookie dough was determined as described by Liang and Were ${ }^{7}$. Radical-scavenging capacity of dough supernatants after 1, 4, 12 and 24 days of refrigerated storage was also measured against 1,1diphenyl-2-picryl-hydrazyl (DPPH) radical (Sigma-Aldrich, USA) $)^{13}$.

\section{Tryptophan fluorescence in sunflower cookie dough}

Tryptophan fluorescence (»EX 280nm, " ${ }_{\mathrm{EM}} 300-500 \mathrm{~nm}$ ) was determined as described by Liang and Were ${ }^{7}$ using a Fluoromax-4 Spectrofluorometer (Horiba Scientific, NJ, USA). A 1:19 dough: DDW, and 1:19 solutions of the major contributors of Trp: wheat flour, sunflower butter and egg ingredients were prepared. Next, Trp FI at $»_{\max }$ of 359nm for egg (1.23x10E7), sunflower butter $(1.98 \times 10 \mathrm{E} 6)$ and wheat $(3.12 \times 10 \mathrm{E} 6)$ was multiplied by $39.4 \%, 24.3 \%$ and $13 \%$ respectively as these were the percentage of these ingredients in dough to estimate their contribution to FI in dough. The Trp fluorescence from sunflower butter dough without leavening was 4.8x10E6. To determine which acidulant quenched Trp most, the Trp FI was also recorded at $359 \mathrm{~nm}$ after increasing volumes of each acidulant was added to pure Trp solution. Since FI of dough without leavening was 4.8x10E6, a Trp solution was prepared to have a similar FI as the Trp FI of unleavened control dough. The Trp solution was diluted till the FI was 
close to 4.8 x10E6 and the concentration of this solution was $2.45 \mathrm{mM}$. The FI of the $2.45 \mathrm{mM} \mathrm{L}-$ tryptophan (Sigma- Aldrich, USA) solution was 4.29 x10E6 CPS. This was used to evaluate changes in Trp FI with acidulants prepared at $9.23-10 \mathrm{mM}$ to correspond to the percentage of acid in dough. The FI and $\mathrm{pH}$ of acidulant-tryptophan solution were recorded after incremental

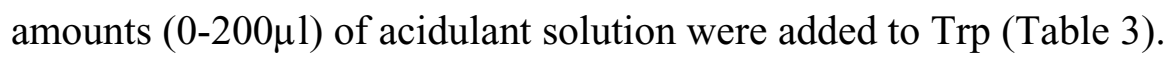

\section{Statistical Analysis}

Two batches of dough with 2 acidulants (citric acid and glucono-delta lactone) and 2 leavening agents (baking powder and baking soda dough leavened) were used to assess greening prevention and oxidation stability at 4 storage times $(1,4,12$, and 24 days) at 8 Conanges in dough color, $\mathrm{pH}$, phenolic content, Folin-Ciocalteu, DPPH reducing capacity, and tryptophan were determined by analysis of variance (ANOVA) followed by post hoc LSD test using SAS statistical analysis software ${ }^{14}$. The level of significance used was $\pm=0.05$. Correlations between Folin-Ciocalteu reducing capacity, phenols, greening $\left(\mathrm{a}^{*}\right)$ and $\mathrm{pH}$ were also determined.

\section{RESULTS AND DISCUSSION}

\section{Sunflower cookie dough color, and pH changes as a function of acidulants and storage time}

Baking powder leavened dough had higher $\mathrm{a}^{*}$ values (Figure 1) attributed to its lower $\mathrm{pH}$ than baking soda leavened dough with higher $\mathrm{pH}$ and lower $\mathrm{a}^{*}$ values. Baking soda control had the lowest a* value on all days. Light greening in baking soda control (BSC) was observed within 4-6 hours, and its $\mathrm{pH}$ was 7.65 on day 1 . The a* value of $\mathrm{BSC}$ decreased while its $\mathrm{pH}$ increased during refrigeration with a final $\mathrm{pH}$ of 9.18 on day 24 . Liang \& Were $^{8}$ reported that alkaline $\mathrm{pH}$ favored greening in cookies formulated with baking soda. Sodium bicarbonate 
(baking soda) in the presence of heat produces $\mathrm{CO}_{2}$ and sodium carbonate, which has a higher $\mathrm{pH}$ than sodium bicarbonate and accounts for increased $\mathrm{pH}$ with time ${ }^{15}$. Formation of sodium carbonate with accompanying $\mathrm{pH}$ increase usually occurs with heating. Our results however showed that long term storage of dough was also accompanied by greening and $\mathrm{pH}$ increase at refrigerated storage. Increased dough volume was however not measured over time to determine $\mathrm{CO}_{2}$ production. This would be further confirmation that the $\mathrm{pH}$ increase was due to baking soda producing $\mathrm{CO}_{2}$ and sodium carbonate during refrigerated storage.

The increased $\mathrm{pH}$ of $\mathrm{BSC}$ resulted in a $62 \%$ increase in greening $\left(-\mathrm{a}^{*}\right)$ after 12 days because alkaline $\mathrm{pH}$ favors green pigment formation (Table 1, Figure 1, Table S1). This green pigment has been identified to be a trihydroxybenzacridine (TBA) derivative, which is produced when oxidized dimers of CGA react with most amino acids, except cysteine, tryptophan, proline, serine, and threonine ${ }^{9,16}$. As expected, added acids lowered $\mathrm{pH}$ of both baking soda and baking powder acidified doughs to prevent greening. The decrease in $\mathrm{pH}$ was due to intrinsic differences in acidulants. These acidulants can also produce carbonic acid when acids react with bicarbonate, but carbonic acid can further degrade to $\mathrm{CO}_{2}$ and water ${ }^{17}$. The $\mathrm{pH}$ of acidified baking soda dough ranged from 6.32-6.79 on day 1 and decreased to 5.53-6.98 on day 24 . In both baking powder and baking soda leavened doughs, citric acid lowered $\mathrm{pH}$ more than GDL. The parts by weight of each acid needed to neutralize available bicarbonate depends on the reactivity of the acidulant, so residual acid would decrease $\mathrm{pH}$ in the dough but if no acid is present, then $\mathrm{pH}$ increases overtime. 
Unlike BSC, acidified doughs did not green with time ( $\mathrm{a}^{*}$ of 3.17 to 4.27 ) except for baking soda leavened dough with GDL (GS) whose $\mathrm{a}^{*}$ decreased from 3.95 to 1.54 on day 24 resulting in slight greening in GS dough (Figure 1, Table S1). Slight greening was observed in GS. The greening observed on day 24 in GS, was from slow GDL hydrolysis during refrigeration. GDL hydrolysis to gluconic acid increases with temperature $\left(20-70^{\circ} \mathrm{C}\right)^{18}$, and slower hydrolysis could thus have occurred at refrigeration temperature. The $\mathrm{pH}$ remained close to neutral (6.6 - 6.9) on days 12 and 24 , which could also account for decrease $\mathrm{a}^{*}$ and some greening in GS dough (Figure 1; Table S1). The increase in greening may have been faster than the $\mathrm{pH}$ lowering when GDL was added in baking soda dough, resulting in the same sample (GS) forming the same green TBA pigment as BSC but at a lower intensity. Compared to baking soda leavened dough, the $\mathrm{pH}$ and $\mathrm{a}^{*}$ of baking powder leavened dough was higher. Baking powder control had an initial $\mathrm{pH}$ of 7.02 , which increased to $\mathrm{pH} 7.13$ on day 24 , resulting in numerical non-significant decrease of a* (2.71 to 2.02); and slight greening at this neutral $\mathrm{pH}$ on day 24 . Our results are consistent with studies by Yabuta et al. ${ }^{9}$ who reported that greening could occur slowly at neutral $\mathrm{pH}$.

With extended storage after 12 days, the color of BSC turned blue (Figure 1c) with $b^{*}$ values progressing to negative values while baking soda control (BSC) was not blue (Table S1). The $\mathrm{b}^{*}$ of BSC decreased from 5.15 to -0.55 , on day 24 , and did not change back to green (Figure 1c, Table S1). This blue TBA pigment formed after prolonged storage ${ }^{9}$. As expected blueness only occurred in BSC which was also the only sample that was green from day 1 . The 
blueness observed in BSC was absent in acidified baking soda and baking powder leavened doughs (Figure 1, Table S1) whose $\mathrm{b}^{*}$ values were positive.

The $b^{*}$ of citric acid and GDL acidified baking soda leavened dough ranged between 3.65 and 6.76 after 24 days of storage compared to lower $b^{*}$ of -0.55 in BSC. The $b^{*}$ of acidified doughs with baking powder ranged between 5.78 and 8.66 compared to 4.65 in BPC on day 24 (Figure 1). On day 12 and 24, baking soda leavened doughs acidified with citric acid had lower $\mathrm{pH}$ and higher $\mathrm{b}^{*}$ values when compared to GDL acidified doughs. In baking powder dough, $\mathrm{pH}$ was not significantly different $(\mathrm{p}>0.05)$ on most days, but was lower than that of the control. Overall, these acidulants could have prevented interaction between CGA quinone and amino acids in dough at the low $\mathrm{pH}$ resulting in either low greening or non-green dough, as observed by positive $\mathrm{a}^{*}$ and $\mathrm{b}^{*}$ values in acidified doughs.

\section{Hydroxycinnamic acid content and reducing capacity of sunflower dough with time Acidulant effect on hydroxycinnamic acid content in sunflower dough with storage time}

The hydroxycinnamic acids (HA) containing ingredients in sunflower dough were wheat,

maple syrup, and sunflower butter. Both BSC and baking powder control (BPC) had lower HA than dough with added acids. The initial HA in BSC of $11.58 \mathrm{mg} / \mathrm{g}$, decreased by $27.62 \%$ after 24 days of refrigerated storage. In contrast to decreased HA in BSC, the HA of BPC increased from 25 to $62.76 \mathrm{mg} / \mathrm{g}$ (Table 2). This higher HA in BPC could be related to higher hunter a* values at neutral $\mathrm{pH}$ (7.13) compared to higher greening in $\mathrm{BSC}$ at alkaline $\mathrm{pH}$ (9.18). The correlation between HA and $\mathrm{pH}$ ranged between -0.19 to -0.83 over time. Since greening only 
occurs at alkaline $\mathrm{pH}^{9,16}$, acidic $\mathrm{pH}$ did not favor interaction between CGA quinones and amino acids, resulting in higher soluble HA (Table 2).

The HA of acidified baking soda doughs was greater than that of BSC on day 1. On the other hand, the HA of baking powder leavened dough with added GDL and citric acid were similar to those of BPC (Table 2). After 24 days, HA of baking soda and baking powder acidified doughs was higher than that of BSC and BPC controls. Compared to their initial values on day 1, the HA of all samples with BP and acidified samples with BS increased significantly $(\mathrm{p}<0.05)$ with storage time (Table 2$)$. This trend could be related to the extent of quinone reduction to parent phenols as well as $\mathrm{pH}$ decrease in the presence of acids (Figure 1, Table S1S2). Although no acid was added to BPC, baking powder used contains sodium aluminum phosphate leavening acid. Acidulants in dough could have prevented CGA oxidation by either competing with primary amines, reducing o-quinones hence regenerating CGA by donating protons to phenoxyl radical, or by lowering $\mathrm{pH}^{19,20}$. Iglesias et al., ${ }^{21}$ for instance reported that caffeic acid was regenerated in the presence of ascorbic acid, while Sastry and Rao ${ }^{22}$ found that CGA-protein binding sites decreased when $\mathrm{pH}$ decreased with less binding at $\mathrm{pH} 5.5$ and 7.0 compared to alkaline $\mathrm{pH}$. Our LC chromatographs (Figure S1) indicated that CGA was greater in acidified in acidified doughs, compared to BSC controls consistent with Table 2. Liang \& Were ${ }^{8}$ likewise reported less greening in a $10 \%(\mathrm{w} / \mathrm{v})$ solution of sunflower butter cookies made with honey whose $\mathrm{pH}$ was lower (honey $\mathrm{pH}$ 3.9) compared to cookies with maple syrup ( $\mathrm{pH}$ of maple syrup 6.3), because of honey's higher acidity stemming from gluconic and other acids. 
Acidified doughs had lower $\mathrm{pH}$ and higher HA than doughs without acid (Table 1), confirming the hypothesis that acidic $\mathrm{pH}$ could prevent phenol oxidation and reduce quinones formed. Acidulants also possibly increased soluble phenols by releasing CGA and ferulic acid from the cookie dough resulting in increased soluble HA. Shchekoldina and Aider $^{4}$ reported increased solubility of phenols when succinic acid was used to extract phenols from sunflower, and similar effects could have been observed in the current study. The extent to which release of bound phenolics using the leavening acids compared to succinic acid needs to however be

confirmed. In addition, Bau et al., ${ }^{23}$, reported higher stability of soluble phenolic compounds in sunflower kernels which had been soaked in citric acid, because of decreased phenol oxidation due to citric acid's chelating ability. Adding acids may thus have stabilized the phenols ${ }^{19,20}$, and without acidulants, the alkaline $\mathrm{pH}$ also promoted the interaction between CGA quinones and amino acids ${ }^{9,16}$. A negative potential nutritional effect of CGA quinone and amino acid binding could be decreased bioavailability of amino acids ${ }^{24}$ and lowered free phenolic compounds.

\section{Acidulant effect on Folin-Ciocalteu and DPPH reducing capacity of sunflower butter dough during refrigerated storage}

Since greening could decrease free CGA in dough, the reducing capacities of phenols was measured to assess the effect of added acidulants. Compared to baking soda doughs, baking powder doughs had higher Folin-Ciocalteu reducing capacity (FCRC) values. The higher FCRC in baking powder leavened dough compared to baking soda leavened dough was attributed to higher HA in baking powder doughs. The FCRC of BSC was significantly lower $(\mathrm{P}<0.05)$ than acidified doughs and increased in the order CSHGS>BSC on day 24 (Figure 2a). 
Baking powder control had an initial FCRC of $3.61 \mathrm{mg} / \mathrm{ml}$ which decreased by $12.06 \%$ on day 24. In acidified BP dough, the initial FCRC was $23.62 \%$, and $5.83 \%$ higher in CP and GP respectively compared to BPC (Figure $2 \mathrm{~b}$ ). In acidified sunflower doughs, acidulants lowered $\mathrm{pH}$ which prevented phenol oxidation and may also have reduced quinone dimers to their parent phenolic compounds, which is consistent with previous studies ${ }^{19}$.

There was no change in FCRC in baking powder doughs on day 24 compared to their initial concentrations, an indication that the reducing capacity of phenolic compounds was stable with time. In addition, the FCRC of BSC remained lower than that of acidified dough on day 24 attributed to the instability of phenolic compounds at alkaline $\mathrm{pH}$, resulting in CGA quinones reacting with amino groups in protein ${ }^{9}$. The $\mathrm{pH}$ of BSC increased from 7.65 on day 1 to 9.18 over 24 days (Figure 2). The correlation between FCRC and $\mathrm{pH}$ ranged between -0.38 and -0.77 , in leavened controls, and GS, an indication that a decrease in $\mathrm{pH}$ resulted in a moderate increase in FCRC.

Comparable to FCRC, the DPPH reducing capacity of baking soda leavened dough was lower than that of baking powder leavened dough (Figure 2), with BSC having the lowest DPPH attributed to the greening reaction ${ }^{9}$. Liang \& $\mathrm{Were}^{8}$ reported that chlorogenic acid-protein interaction lowered CGA content, consistent with our results where the FCRC/phenol content of BSC decreased (Table 2) with higher greening. Over time, the DPPH in BSC, CS and GS increased by $3.95 \%, 23.82 \%$, and $63.94 \%$, respectively after 24 days compared to their initial DPPH values. In general, the increase in DPPH over time was greater with baking powder 
doughs, since baking powder contains SALP leavening acid, hence the lower $\mathrm{pH}$ compared to baking soda (Table 1). The DPPH of BPC, CP and GP increased by $91.81 \%, 51.72 \%$ and $18.43 \%$ after 24 days compared to their initial concentration (Figure 2). This increase in DPPH over time could be attributed to the reduction of quinones back to their reduced forms or release of soluble phenols with acidulants ${ }^{19}$. The soluble phenol compounds increased at acidic $\mathrm{pH}$ resulting in higher DPPH reducing capacities (Table 2). Many antioxidant in-vitro assays are sensitive to $\mathrm{pH}$, and differences in $\mathrm{pH}$ of the doughs in addition to the intrinsic properties of the acidulants may have also affected the results. It has been reported ${ }^{25,26}$ that when methanol is used as solvent, $\mathrm{pH}$ is not a concern for DPPH analysis.

The DPPH reducing capacity of BSC was significantly lower $(\mathrm{p}<0.05)$ compared to acidified doughs with baking soda. The DPPH of doughs formulated with baking soda and acidified with citric acid and GDL were $65 \%$, and 30\% higher on day 1 and 97\%, 104\% higher on day 24 compared to BSC on those days respectively. CGA quinone binding to amino acids could have been responsible for the lower reducing capacity in $\mathrm{BSC}^{8}$. Increased free phenols in acidified doughs accounted for higher DPPH reducing capacity compared to non-acidified controls.

There was a weak negative correlation (-0.15 to -0.31$)$ between FCRC and DPPH in all samples. The DPPH reducing capacity of all acidified baking powder doughs was not significantly different from that of BPC on all days of analysis (Figure 2). Baking powder control contained SALP leavening acid which could have also prevented phenol oxidation, accounting 
for DPPH reducing capacity that was comparable to the reducing capacity of acidified doughs. The lower $\mathrm{pH}$ of baking powder doughs could decrease phenol oxidation and hence higher DPPH reducing capacity when compared to the baking soda leavened dough. Altunkaya \& Gokmen $^{19}$, reported that citric and ascorbic acid prevented phenolic oxidation by reducing quinone and thus low $\mathrm{pH}$ prevented phenol oxidation.

\section{Acidulant effect on tryptophan fluorescence of chemically leavened dough}

Tryptophan is one of the amino acids besides cysteine, proline, serine, and threonine which does not produce green trihydroxybenzacridine (TBA) derivatives upon reacting with oxidized dimers of $\mathrm{CGA}^{9,16}$. It was however important to monitor Trp fluorescence as an indicator of changes in this essential amino acid due to reactions with oxidized lipids and quinones $^{28}$, since polyphenols can lower its bioavailability in the dough ${ }^{24}$. The Tryptophan FI of both baking soda and baking powder leavened doughs was lower than that of non-leavened and non-acidified control dough. Tryptophan Fluorescence intensity (FI) of baking soda dough was however higher than that of baking powder dough (Figure 3) and this could be because of differing interactions between the leavening agents with acidulants and Trp. In addition to lower Trp FI, a red shift was observed in leavened doughs when compared to non-leavened and nonacidified controls. The maximum Trp FI wavelength in non-leavened and non-acidified control was $330 \mathrm{~nm}$. Compared to non-leavened dough solutions, a red shift of $24-31 \mathrm{~nm}$ occurred in doughs formulated with baking soda (Figure 3a) on day 1 while red shift of 27-30 nm was observed in doughs made with baking powder (Figure $3 \mathrm{~b}$ ) on day 1 . The red shifts were an indication that stronger conformational changes occurred in leavened doughs. Similarly, on day 
24 , a red shift of $20-33 \mathrm{~nm}$ was observed for baking soda doughs (Figure 3c), while a red shift of 29-31nm was observed in baking powder doughs (Figure 3d), compared to FI at »max (330 nm) in non-leavened dough control on day 1 .This red shift also indicated that Trp residues were in a more hydrophilic environment as the protein conformation changed after acidification ${ }^{5,27}$.

Tryptophan FI of acidified dough differed with added acids, compared to non-leavened dough. Compared to BSC, Trp FI was not significantly different $(\mathrm{p}>0.05)$ on day 1 . On day 1 , Trp FI decreased in the order: non-acidified and non-leavened dough $<\mathrm{GS}<\mathrm{CS}<\mathrm{BSC}$. In baking powder dough, Trp FI on day 1, decreased in the order non-acidified and non-leavened dough $<\mathrm{BPC}<\mathrm{GP}<\mathrm{CP}$ compared to the control (Figure 3). After 24 days, the same trend was observed, although Trp of baking powder dough was lower than Trp in baking soda doughs. Baking powder doughs were more acidic than baking soda doughs, and thus quenched Trp more than less acidic baking soda doughs. The correlation between Trp and FCRC ranged from -0.30 to -0.73 in baking soda dough. This correlation could be because oxidized CGA dimer and monomer can react with Trp, so an increase in free phenol could decrease Trp.

At the same ingredient concentration in the dough, the Trp FI of ingredients containing Trp was ranked as egg $>$ wheat flour $>$ sunflower butter with the Trp FI of egg being $74.63 \%$ higher than Trp FI of wheat flour, and 83.90\% higher than Trp FI of sunflower butter. The Trp FI of non-acidified dough was $4.8 \times 10 \mathrm{E} 6$, while the sum of Trp from egg, wheat and sunflower butter was less $(3.38 \mathrm{x} 10 \mathrm{E} 6)$. The maximum FI of Trp solution at $359 \mathrm{~nm}$ of $4.29 \mathrm{E}+06$ was diluted to be similar to the FI of non-acidified dough. 
To further elucidate the effect of acidulants on Trp, acidulants were added to a $2.45 \mathrm{mM}$, Trp solution and Trp fluorescence was monitored (Table 3). The pH of $2.45 \mathrm{mM} \operatorname{Trp}$ was 4.82 and decreased to 2.86 and 2.77 with $120 \mu 1$ added gluconic acid and citric acid respectively (Table 3). Increasing the volume of each acidulant decreased $\mathrm{pH}$ and Trp FI. After adding $200 \mu 1$ of each acidulants, Trp FI decreased by $15 \%$ and $18 \%$ in Trp solution with added citric and gluconic acid (Table 3). The moderate negative correlation (-0.26 to -0.69$)$ between $\mathrm{pH}$ and $\operatorname{Trp}$ of dough solutions at $\rangle_{\mathrm{EX}} 280 \mathrm{~nm}$, $\rangle_{\mathrm{EM}} 359 \mathrm{~nm}$ (Figure 3), could indicate that decreased Trp was attributed to quenching by acidulants or crosslinking with CGA in addition to Trp oxidation ${ }^{28}$. Tryptophan is an essential amino acid susceptible to oxidation, so lower Trp as a function of acidulant could signal some loss during storage.

\section{CONCLUSION}

Acidulants prevented greening in baking soda and baking powder leavened sunflower dough by decreasing $\mathrm{pH}$ since chlorogenic acid quinone and amino acid do not bind to each other at acid $\mathrm{pH}$. In addition to lowering $\mathrm{pH}$, which prevents greening, acidulants contribute to leavening in sunflower dough but does not degrade phenols. The phenolic compounds in acidified dough still maintained their reducing capacity over time as assessed by FCRC and DPPH. The reducing capacities of acidified doughs were significantly higher than that of nonacidified controls. In contrast to reducing capacities, the Trp fluorescence of acidified doughs was lower than that of non-acidified controls. Further investigations could include sensory 
testing of cookies made with acidified dough to compare balance between lowered greening with taste.

\section{ACKNOWLEDGEMENT}

This research was financially supported by Chapman University.

\section{REFERENCES}

1. USDA. Basic Report: 12036, Seeds, sunflower seed kernels, dried, https://ndb.nal.usda.gov/ndb/foods/show/3626; (2018) [cited on Jun 29 2018].

2. FDA. U.S Food and Drug Administration. Food Allergies: What You Need to Know., https://www.fda.gov/Food/ResourcesForYou/Consumers/ucm079311.htm; (2017) [cited on Jun 29 2018].

3. Weisz GM, Kammerer DR, Carle R. Identification and quantification of phenolic compounds from sunflower (Helianthus annuus L.) kernels and shells by HPLCDAD/ESI-MSn. Food Chem 115:758-765 (2009).

4. Shchekoldina T, Aider M. Production of low chlorogenic and caffeic acid containing sunflower meal protein isolate and its use in functional wheat bread making. J Food Sci Techn-Mysore 51:2331-2343 (2014).

5. Kang J, Liu Y, Xie MX, Li S, Jiang M, Wang YD. Interactions of human serum albumin with chlorogenic acid and ferulic acid. Biochim Biophy Acta-Gnrl Subj 1674:205-214 (2004).

6. Prigent SVE, Voragen AGJ, Li F, Visser A, van Koningsveld GA, Gruppen H. Covalent interactions between amino acid side chains and oxidation products of caffeoylquinic acid (chlorogenic acid). J. Sci Food Agric 88:1748-1754 (2008).

7. Liang S, Were LM. Chlorogenic acid induced colored reactions and their effect on carbonyls, phenolic content, and antioxidant capacity in sunflower butter cookies. LWT Food Sci Tech 87:16-22 (2018).

8. Liang SH, Were LM. Chlorogenic acid oxidation-induced greening of sunflower butter cookies as a function of different sweeteners and storage conditions. Food Chem 241:135-142 (2018).

9. Yabuta G, Koizumi Y, Namiki K, Hida M, Namiki M. Structure of green pigment formed by the reaction of caffeic acid esters (or chlorogenic acid) with a primary amino compound. Biosci Biotech and Biochem 65:2121-2130 (2001).

10. Univar. Chemical Leavening, http://www.univar.com/ /media/PDFs/CA\%20Region\%20PDFs/Food\%20Ingredients/Fo 
od\%20Function\%20Library/Univar\%20Function\%20Library\%20-

\%20Chemical\%20Leavening.ashx accessed Jun 29 2018].

11. Win MM, Abdul-Hamid A, Baharin BS, Anwar F, Sabu MC, Pak-Dek MS. Phenolic compounds and antioxidant activity of peanut's skin, hull, raw kernel and roasted kernel flour. Pakis J Bot 43:1635-1642 (2011).

12. Simsek S. Application of xanthan gum for reducing syruping in refrigerated doughs. Food Hydrocol 23(8):2354-2358 (2009).

13. Fan LS, Zhang SH, Yu L, Ma L. Evaluation of antioxidant property and quality of breads containing Auricularia auricula polysaccharide flour. Food Chem 101:1158-1163 (2007).

14. SAS Institute Inc. 2011. Base SAS® 9.3 Procedures Guide. Cary, NC: SAS Institute Inc. (2011).

15. Kweon M, Slade L, Levine H, Gannon D. Cookie- Versus Cracker-Baking-What's the Difference? Flour Functionality Requirements Explored by SRC and Alveography. Crit Rev Food Sci 54:115-138 (2014).

16. Bongartz V, Brandt L, Gehrmann ML, Zimmermann BF, Schulze-Kaysers N, Schieber A. Evidence for the Formation of Benzacridine Derivatives in Alkaline-Treated Sunflower Meal and Model Solutions. Molecules 21:91- 96 (2016).

17. Heidolph BB. Designing chemical leavening systems. Cereal Foods World 41:118-126 (1996).

18. PMP Fermentation Products. Glucono-delta lactone, http://www.pmpinc.com/documents/gdl-brochure.pdf; (1992).

19. Altunkaya A, Gokmen V. Effect of various anti-browning agents on phenolic compounds profile of fresh lettuce (L. sativa). Food Chem 117:122-126 (2009).

20. Chow YN, Louarme L, Bonazzi C, Nicolas J, Billaud C. Apple polyphenoloxidase inactivation during heating in the presence of ascorbic acid and chlorogenic acid. Food Chem 129:761-767 (2011).

21. Iglesias J, Pazos M, Andersen ML, Skibsted LH, Medina I. Caffeic Acid as Antioxidant in Fish Muscle: Mechanism of Synergism with Endogenous Ascorbic Acid and alphaTocopherol. J Agric Food Chem 57:675-681 (2009).

22. Sastry MCS, Rao MSN. Binding of chlorogenic acid by the isolated polyphenol-free $11 \mathrm{~S}$ protein of sunflower (Helianthus annuus) seed. J Agric Food Chem 38:2103-2110(1990).

23. Bau HM, Mohtadi-Nia DJ, Mejean L, Debry G. Preparation of colorless sunflower protein products: effect of processing on physicochemical and nutritional properties. $J$ Amer Oil Chem Soc 60:1141-1148 (1983).

24. Jakobek L. Interactions of polyphenols with carbohydrates, lipids and proteins. Food Chem 175:556-567(2015).

25. Ozgen M, Reese RN, Tulio AZ, Scheerens JC, Miller AR. Modified 2,2-azino-bis-3ethylbenzothiazoline-6-sulfonic acid (ABTS) method to measure antioxidant capacity of selected small fruits and comparison to ferric reducing antioxidant power (FRAP) and 2,2 '-diphenyl-1-picrylhydrazyl (DPPH) methods. J Agric Food Chem 54:1151-1157 (2006). 
26. Ozcelik B, Lee JH, Min DB. Effects of light, oxygen, and pH on the absorbance of 2,2diphenyl-1-picrylhydrazyl. J Food Sci 68:487-490 (2003).

27. Li XR, Yang ZH, Bai YL. Fluorescence spectroscopic analysis of the interaction of papain and bromelain with L-ascorbic acid, alpha-tocopherol, beta-carotene and astaxanthin. Int J Bio Macromol 107:144-156 (2018).

28. Friedman M. Food browning and its prevention: An overview. J Agric Food Chem 44:631-653 (1996). 


\section{List of Tables}

Table 1: Changes in $\mathrm{pH}$ of baking soda and baking powder leavened dough as a function of added acids and time.

\begin{tabular}{|c|c|c|c|c|c|c|}
\hline \multirow{2}{*}{$\begin{array}{l}\text { Time } \\
\text { (days) }\end{array}$} & \multicolumn{2}{|c|}{ Doughs with baking soda } & \multicolumn{4}{|c|}{ Doughs with baking powder } \\
\hline & $\mathrm{BSC}$ & $\mathrm{BS}+\mathrm{CA}$ & $\mathrm{BS}+\mathrm{GDL}$ & BPC & $\mathrm{BP}+\mathrm{CA}$ & $\mathrm{BP}+\mathrm{GDL}$ \\
\hline 1 & $7.65 \pm 0.08^{\mathrm{a}}{ }_{\mathrm{B}}$ & $6.79 \pm 0.12^{\mathrm{c}} \mathrm{A}$ & $7.53 \pm 0.01^{\mathrm{a}}{ }_{\mathrm{A}}$ & $7.02 \pm 0.03^{b}$ & $6.32 \pm 0.13^{\mathrm{d}}{ }_{\mathrm{B}}$ & $6.45 \pm 0.03^{\mathrm{d}}{ }_{\mathrm{A}}$ \\
\hline 12 & $9.10 \pm 0.35_{\mathrm{A}}^{\mathrm{a}}$ & $6.19 \pm 0.09^{\mathrm{cd}}{ }_{B}$ & $6.60 \pm 0.23^{\mathrm{c}}$ & $7.85 \pm 0.07^{\mathrm{b}}$ & $4.83 \pm 0.21_{\mathrm{A}}^{\mathrm{e}}$ & $5.57 \pm 0.45^{\mathrm{d}}{ }_{\mathrm{B}}$ \\
\hline 24 & $9.18 \pm 0.09^{\mathrm{a}}{ }_{\mathrm{A}}$ & $6.17 \pm 0.09^{\mathrm{c}}{ }_{\mathrm{B}}$ & $6.98 \pm 0.05^{\mathrm{b}}{ }_{\mathrm{B}}$ & $7.135 \pm 0.11^{\mathrm{b}}$ & $5.46 \pm 0.31_{\mathrm{AB}}^{\mathrm{d}}$ & $5.36 \pm 0.06^{\mathrm{d}}{ }_{\mathrm{B}}$ \\
\hline \multicolumn{7}{|c|}{$\mathrm{CA}=$ citric acid, $\mathrm{GDL}=$ glucono delta lactone } \\
\hline \multicolumn{7}{|c|}{$\begin{array}{l}\text { Treatments with the same superscript letter in the same row (same day) are not significantly } \\
\text { different on that day. }\end{array}$} \\
\hline
\end{tabular}


Table 2: Hydroxycinnamic acid concentration $(\mathrm{g} / \mathrm{Kg})$ in baking soda and baking powder leavened dough with added acids

\begin{tabular}{|c|c|c|c|c|c|c|}
\hline \multirow{2}{*}{$\begin{array}{l}\text { Time } \\
\text { (days) }\end{array}$} & \multicolumn{3}{|c|}{ Baking Soda/BS leavened doughs } & \multicolumn{3}{|c|}{ Baking powder/BP leavened doughs } \\
\hline & BSC & $\mathrm{BS}+\mathrm{CA}$ & $\mathrm{BS}+\mathrm{GDL}$ & $\mathrm{BPC}$ & $\mathrm{BP}+\mathrm{CA}$ & $\mathrm{BP}+\mathrm{GDL}$ \\
\hline 1 & $11.56 \pm 3.57^{\mathrm{c}} \mathrm{A}$ & $28.56 \pm 5.40^{\mathrm{b}}{ }_{\mathrm{B}}$ & $36.32 \pm 2.36^{\mathrm{b}}{ }_{\mathrm{B}}$ & $25.49 \pm 9.69^{\mathrm{bc}}{ }_{\mathrm{B}}$ & $39.32 \pm 4.57^{\mathrm{b}}$ & $59.62 \pm 7.31^{\mathrm{a}}{ }_{\mathrm{B}}$ \\
\hline 4 & $13.11 \pm 3.41_{\mathrm{A}}^{\mathrm{c}}$ & $75.71 \pm 2.80^{\mathrm{ab}}{ }_{\mathrm{A}}$ & $73.18 \pm 2.15^{\mathrm{ab}} \mathrm{A}$ & $56.59 \pm 8.83^{\mathrm{b}}{ }_{\mathrm{A}}$ & $85.98 \pm 16.51^{a}{ }_{\mathrm{A}}$ & $78.2 \pm 4.37_{\mathrm{A}}^{\mathrm{a}}$ \\
\hline 12 & $9.02 \pm 0.78^{\mathrm{d}}{ }_{\mathrm{A}}$ & $64.00 \pm 14.44_{\mathrm{A}}^{\mathrm{ab}}$ & $43.33 \pm 5.38^{\mathrm{a}}{ }_{\mathrm{B}}$ & $48.61 \pm 3.76^{\mathrm{a}}{ }_{\mathrm{A}}$ & $74.06 \pm 1.44_{\mathrm{A}}^{\mathrm{a}}$ & $66.40 \pm 7.83^{\mathrm{a}}{ }_{\mathrm{AB}}$ \\
\hline 24 & $8.36 \pm 0.84_{\mathrm{A}}^{\mathrm{b}}$ & $69.07 \pm 1.42^{\mathrm{a}} \mathrm{A}$ & $68.96 \pm 7.68^{\mathrm{a}}{ }_{\mathrm{A}}$ & $62.76 \pm 5.10^{\mathrm{a}}{ }_{\mathrm{A}}$ & $74.83 \pm 5.52^{\mathrm{a}}{ }_{\mathrm{A}}$ & $73.72 \pm 0.67^{\mathrm{a}}{ }_{\mathrm{AB}}$ \\
\hline \multicolumn{7}{|c|}{$\mathrm{CA}=$ citric acid, $\mathrm{GDL}=$ glucono delta lactone } \\
\hline \multicolumn{7}{|c|}{$\begin{array}{l}\text { Treatments with the same superscript letter in the same row (same day) are not significantly } \\
\text { different on that day. }\end{array}$} \\
\hline
\end{tabular}




\begin{tabular}{|c|c|c|c|c|}
\hline \multirow{2}{*}{$\begin{array}{l}\text { Acid (ul) } \\
\text { Added to } 5 \mathrm{ml} \text { Trp } \\
(2.45 \mathrm{mM} \mathrm{L}- \\
\text { tryptophan) }\end{array}$} & \multicolumn{2}{|c|}{ Trp Fluorescence Intensity (a.u) } & \multicolumn{2}{|l|}{$\mathbf{p H}$} \\
\hline & $\operatorname{Trp}+$ citric acid & $\operatorname{Trp}+$ GDL & Trp+ citric acid & $\operatorname{Trp}+$ GDL \\
\hline 0 (control/no acid) & $4.29 \mathrm{E}+06$ & $4.29 \mathrm{E}+06$ & 4.82 & 4.82 \\
\hline 40 & $4.21 \mathrm{E}+06$ & $3.90 \mathrm{E}+06$ & 3.32 & 3.25 \\
\hline 80 & $3.75 \mathrm{E}+06$ & $3.63 \mathrm{E}+06$ & 2.9 & 3.04 \\
\hline 120 & $3.74 \mathrm{E}+06$ & $9.42 \mathrm{E}+06$ & 2.77 & 2.86 \\
\hline 200 & $3.66 \mathrm{E}+06$ & $3.51 \mathrm{E}+06$ & 2.71 & 2.8 \\
\hline
\end{tabular}

Table 3 Acidulant effect on tryptophan (Trp) and pH changes 


\section{Figures Captions}

Figure 1: Surface greening (-a*) changes of baking soda (a) and baking powder (b) leavened sunflower butter cookie dough; Changes in $\left(b^{*}\right)$ of baking soda (c) and baking powder (d) leavened sunflower butter dough as a function of acidulant and refrigeration time. Treatments with the same letter on the same day are not significantly different on that day.

Figure 2: Folin-Ciocalteu reducing capacity changes of baking soda (a) and baking powder (b) and changes in DPPH reducing capacity changes in baking soda (c) and baking powder (d) leavened sunflower butter cookie dough as a function of refrigeration time and acidulant. Treatments with the same letter on the same day are not significantly different on that day.

Figure 3: Tryptophan fluorescence intensity of baking soda dough on day 1(a) and day 24 (b) and baking powder dough on day 1(c) and day $24(\mathrm{~d})$, as a function of added acidulants. 
a) Baking soda leavened dough greening and correlation (-0.59 to -0.80) with $\mathrm{pH}$

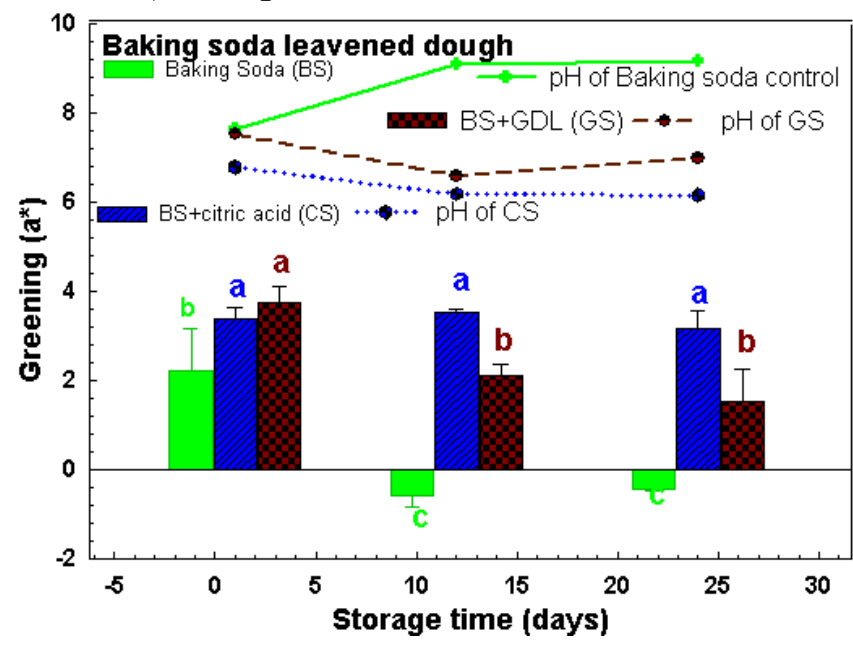

b) Baking powder leavened dough greening and correlation (0.80

to

$0.82)$ with

$\mathrm{pH}$

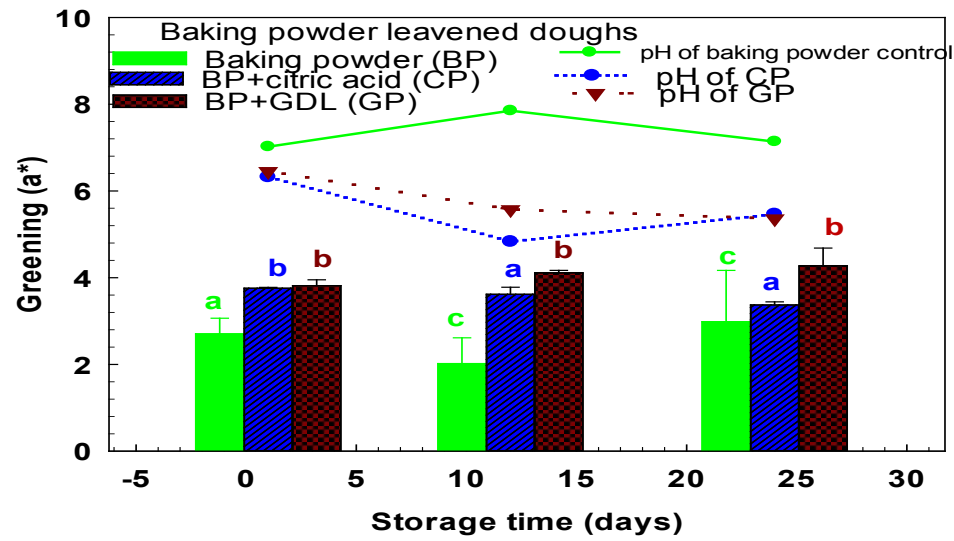


c)Baking soda leavened dough Hunter $b^{*}$ changes with time

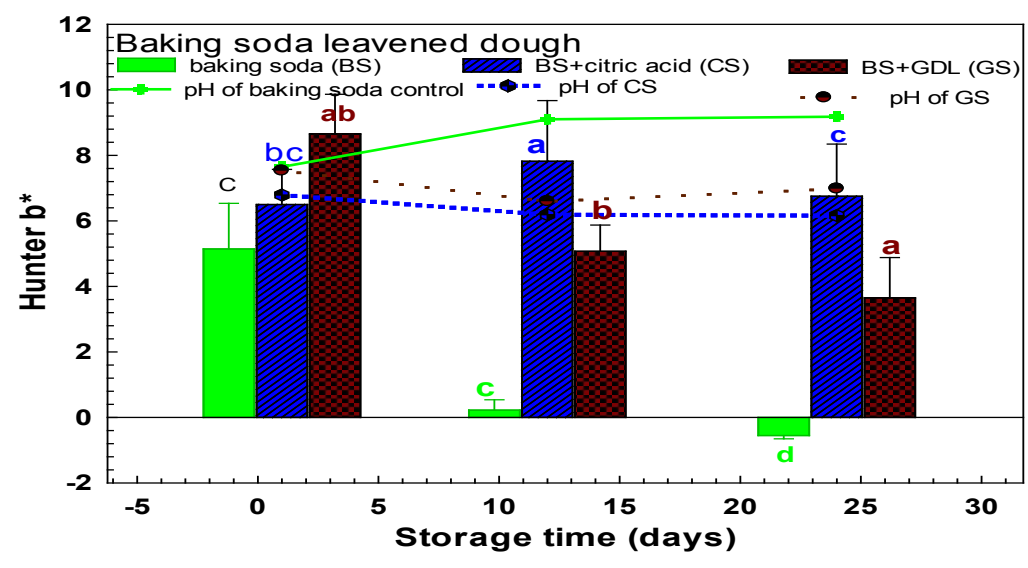

d)Baking powder leavened dough Hunter $b^{*}$ changes with

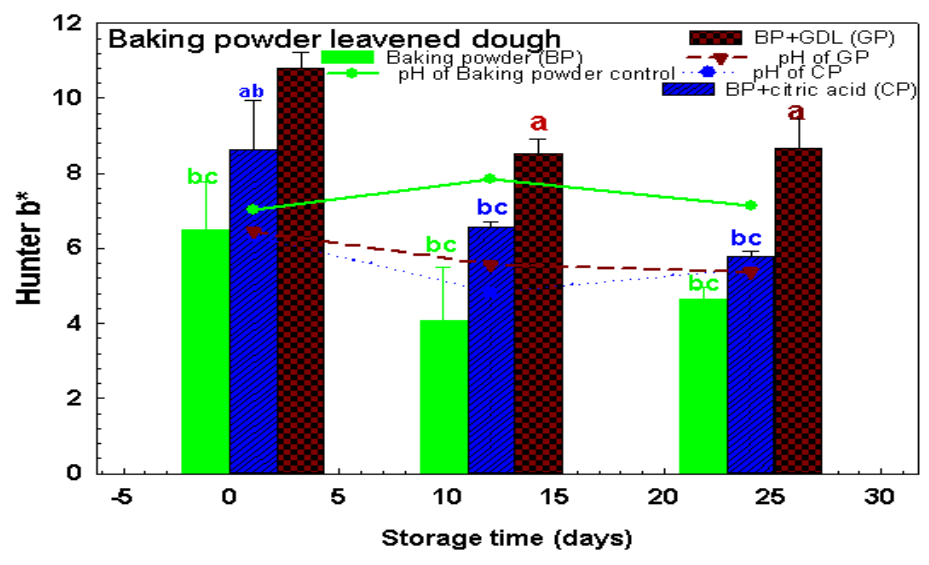

Figure 1 
a) Folin-Ciocalteu reducing capacity of baking soda leavened dough

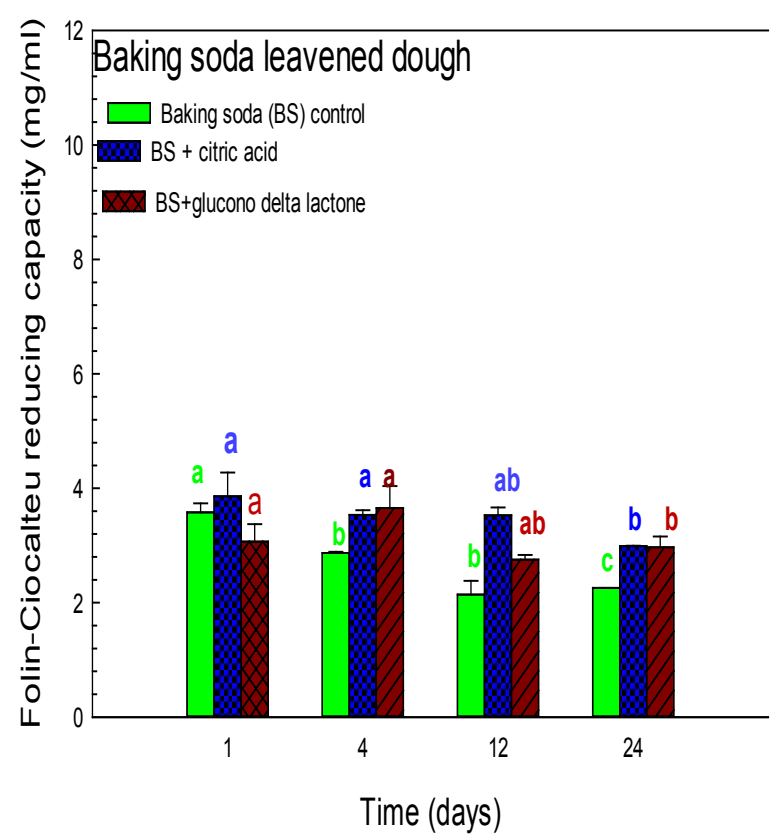

b) Folin-Ciocalteu of baking powder leavened dough

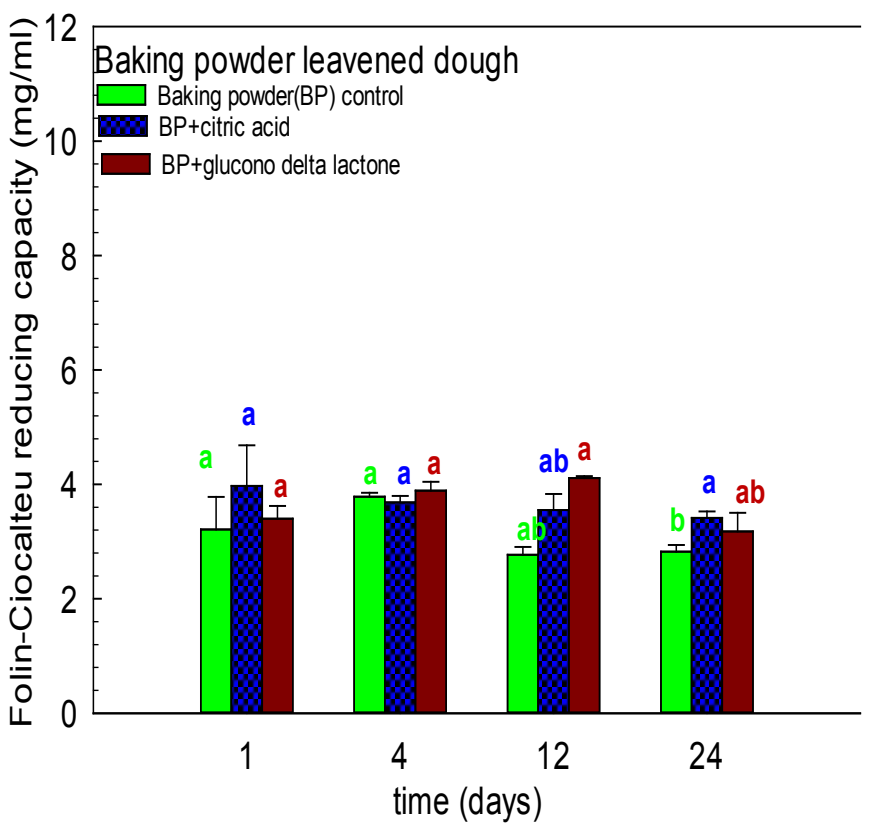


c) DPPH reducing capacity of baking soda leavened dough

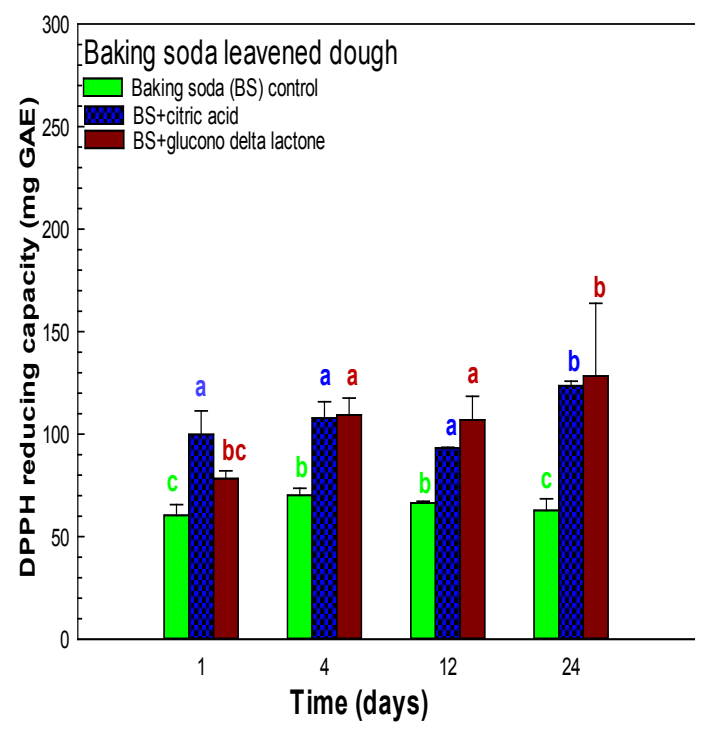

d) DPPH reducing capacity of baking powder leavened dough

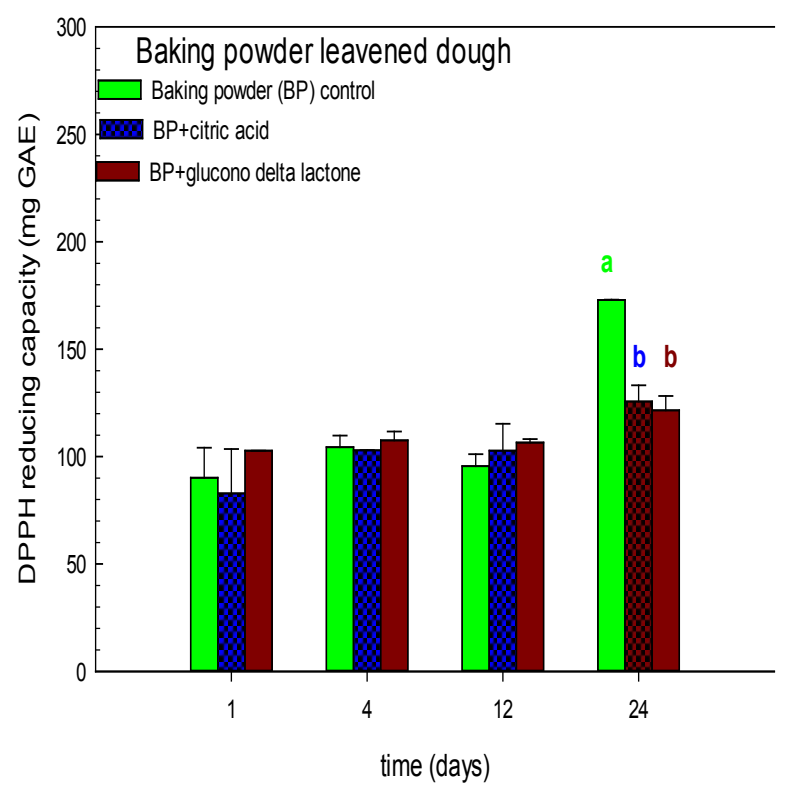

Figure 2 
a) Baking soda tryptophan fluorescence dayl

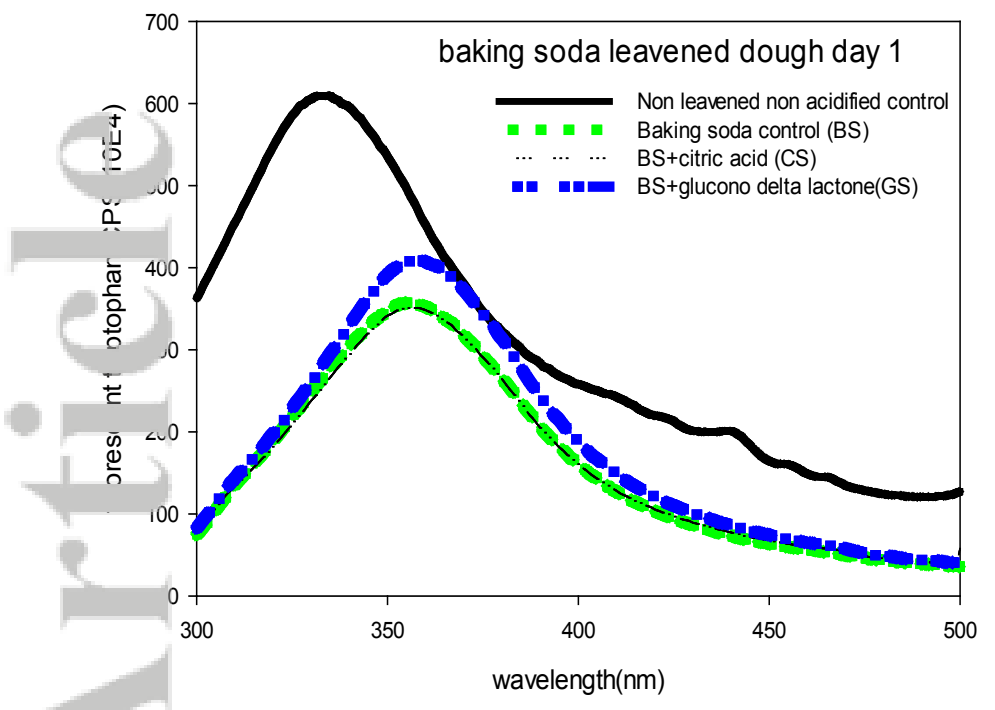

c) Baking soda dough tryptophan fluorescence day 24 b) Baking powder tryptophan fluorescence day1

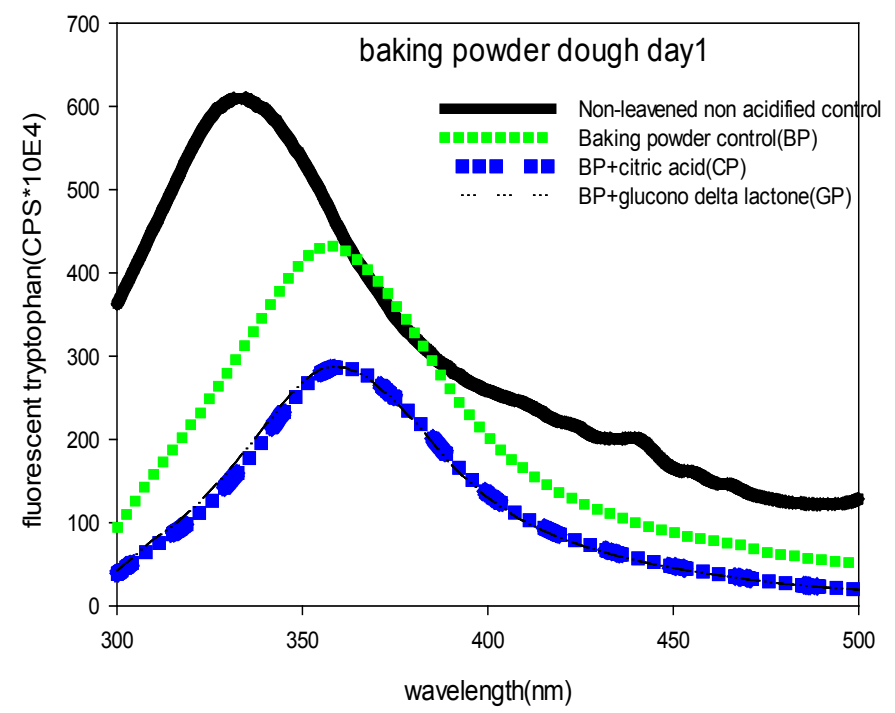

d) Baking powder dough tryptophan fluorescence day 24

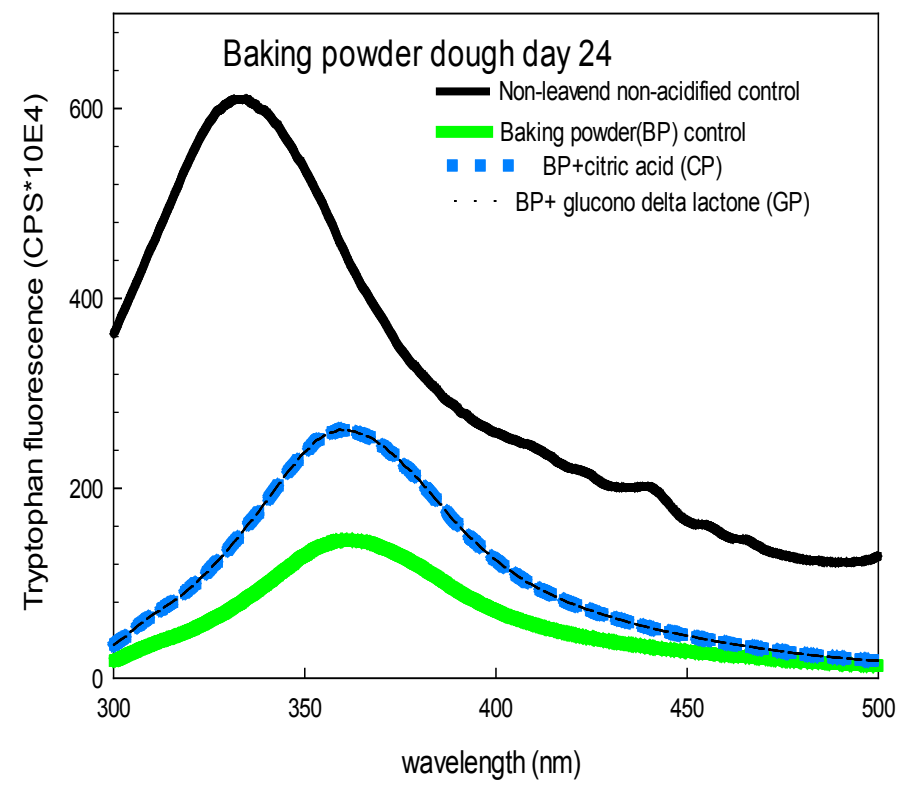

Figure 3 